\title{
Radiological Diagnosis
}

\section{Diagnosis of the case presented in the previous edition}

\section{J Bras Pneumol 2005;31(6):567.}

\section{PERIPHERAL T-CELL LYMPHOMA WITH PULMONARY INVOLVEMENT}

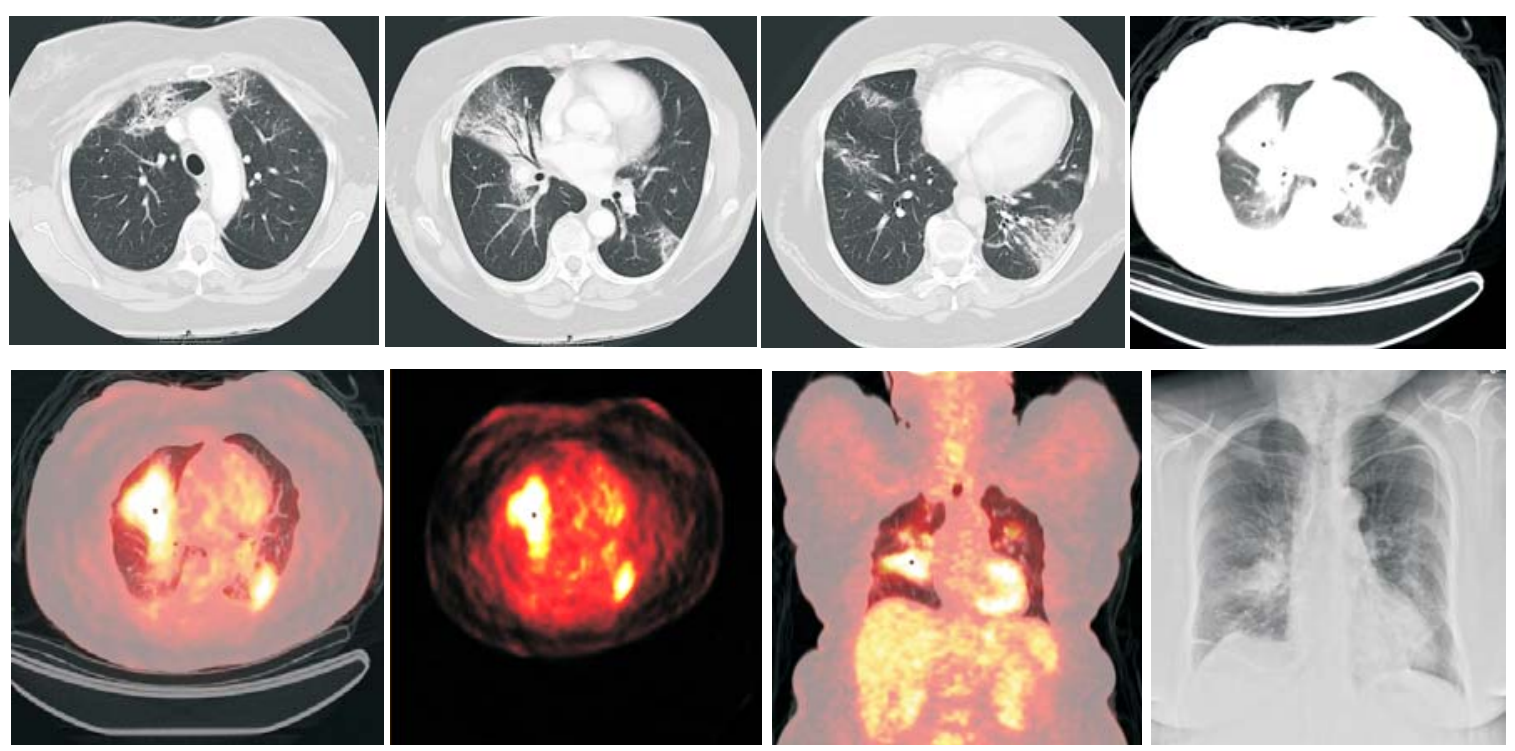

67-year-old female patient with dyspnea for 3 months. Reports a palpable abdominal mass.

\section{COMENTÁRIOS}

According to the WHO classification, lymphomas are divided into T-cell non-Hodgkin's lymphomas, B-cell non-Hodgkin's lymphomas and Hodgkin's disease. The T-cell non-Hodgkin's lymphomas may be peripheral or central.

Peripheral T-cell lymphomas (PTCLs) are more common in oriental countries, accounting for 25\% of all non-Hodgkin's lymphomas in Korea. They can be classified as:

Extranodal nasal T-cell lymphoma

T-cell lymphoma concomitant with enteropathy

Subcutaneous panniculitis-type T-cell lymphoma

Fungoid mycosis/Sezary syndrome

Anaplastic, cutaneous or disseminated large cell

\section{lymphoma}

Hepatosplenic T-cell lymphoma

Angioimmunoblastic T-cell lymphoma

Nonspecific peripheral T-cell lymphoma

Most PTCL cases are aggressive, and the prognosis is poor. The case presented is that of a nonspecific peripheral T-cell lymphoma, with nodal abdominal involvement (palpable mass) and pulmonary alterations. Prognosis is poor, and fiveyear survival is low. Positron emission tomography is of great value in disease staging, treatment control, detection of recurrence, and restaging, especially when coupled with computed tomography. 
DANY JASINOWODOLINSKI; GUSTAVO DE SOUZA PORTES MEIRELLES; NESTOR L MÜLLER Fleury Center for Diagnostic Medicine, São Paulo, São Paulo, Brazil; Universidade Federal de São Paulo (UNIFESP, Federal University of São Paulo), São Paulo, São Paulo, Brazil, University of British Columbia, Vancouver, British Columbia, Canada

\section{REFERENCE}

1. Lee HJ, Im JG, Goo JM, Kim KW, Choi Bl, Chang KH, Han JK, Han MH. Peripheral T-cell lymphoma: spectrum of imaging findings with clinical and pathologic features. Radiographics. 2003;23(1):7-26

\section{READER(S) CORRECTLY DIAGNOSING THE CASE PRESENTED IN THE NOVEMBER/ DECEMBER 2005 ISSUE}

Ednei P. Guimarães - Hospital Júlia Kubitschek - Belo Horizonte - MG

Munira Martins de Oliveira - Hospital Júlia Kubitschek - Belo Horizonte - MG

Ricardo Domingos Delduque - Hospital Padre Albino - Catanduva - SP

Rogério Lima Duarte - Hospital Emílio Carlos - Catanduva - SP

Winston Hidekazu Akashi lwauchi - Hospital São Luiz - São Paulo - SP 